\title{
Rumen Development, Intestinal Growth and Hepatic Metabolism In The Pre- and Postweaning Ruminant*
}

\author{
R. L. Baldwin, VI, ${ }^{1}$ K. R. McLeod, ${ }^{2}$ J. L. Klotz, ${ }^{3}$ \\ and R. N. Heitmann ${ }^{3}$ \\ ${ }^{1}$ Bovine Functional Genomics Laboratory \\ Animal and Natural Resources Institute, Agricultural Research Service, \\ United States Department of Agriculture, Beltsville, MD 20705-2350 \\ ${ }^{2}$ Department of Animal Science \\ University of Kentucky, Lexington 40546 \\ ${ }^{3}$ Department of Animal Science \\ University of Tennessee, Knoxville 37901
}

\begin{abstract}
Both the role of intestinal development and the process of transitioning calves from their neonatal reliance on nutrients supplied from milk to nutrients supplied from grain are of substantial economic importance to the producer. Improvements to the calf nutritional regime can decrease mortality and disease susceptibility, increase postweaning rate of gain, ultimately enhancing the rate of herd genetic improvement (due to increased capacity for voluntary culling). Current feeding practices including daily encouragement to eat grain diets result in weaning from milk by 3 to 4 wk of age. Although the mechanisms are not yet completely understood, development of a viable fermentation within the rumen is required to initiate the maturation of the rumen epithelia. This transition results in tremendous metabolic ramifications to calf growth rate, as tissues must convert from reliance on glucose supplied from milk to the metabolism of short-chain fatty acids as primary energy substrates. This maturation is the result of differential expression of numerous genes regulating both physical and metabolic characteristics of the tissue. While the most dramatic physical changes occurring during development are associated with the rumen epithelium, changes in intestinal mass and metabolism are also realized in response to dietary changes. Amino acid use by the intestinal tissues is high and may affect amino acid availability in support of growth. Moreover, because the metabolic and protein synthetic activities of the digestive tract are high, accounting for up to $30 \%$ of both whole animal energy
\end{abstract}

Received July 18, 2003

Accepted October 26, 2003

Corresponding author: R. L. Baldwin, VI ; e-mail: rbaldwin@anri. barc.usda.gov.

"Presented at a symposium titled "Growth and Development: Intestinal Development in Colostrum" at the ADSA-ASAS Joint Annual Meeting. June 2003, Phoenix, AZ. use and whole animal protein synthesis, understanding their regulation is vital to the continued improvement in calf management. Specific nutrient-gene interactions have been identified across the digestive tract and serve to increase visceral organ mass and directly change nutrient metabolism by the epithelia. Similarly, humoral factors have been identified as having regulatory function over gastrointestinal tissue mass and metabolism. Continuing efforts to better understand the factors affecting intestinal development will improve weaning strategies and foster better postweanling calf growth performance.

(Key words: ruminant, development, weaning, growth)

Abbreviation key: ME = metabolizable energy, PDV = portal-drained viscera, SCFA = short-chain fatty acid.

\section{INTRODUCTION}

Among of the most dramatic physiological challenges to young ruminants are the events surrounding the development of the rumen. This not only entails growth and cellular differentiation by the rumen, but also results in a major shift in the pattern of nutrients being delivered to the intestine and liver, and thus the peripheral tissues of the animal. The rumen epithelium is responsible for several physiologically important functions, including absorption, transport, short-chain fatty acid metabolism, and protection (Stevens, 1969; Galfi et al., 1991). In contrast to the other service function organs, which decline as a percentage of empty BW as the ruminant matures, the rumen increases from 30 to $70 \%$ of the capacity of the gut during the weaning process (Warner et al., 1956). Because of the necessity to digest and absorb nutrients from maternal milk, intestinal tissue undergoes rapid proliferation during fetal development and in the immediate postnatal period (Morisset, 1993). In the 
young, growing ruminant, variations in the type and form of nutrients supplied to the gastrointestinal tract may alter cellular proliferation, total nutrient use by the gut, and ultimately, nutrients available to support growth. The liver serves as the ultimate arbiter of nutrients available to the periphery in support of growth, and must adapt to patterns of nutrients absorbed as a result of rumen development. In the preruminant, the liver serves as the primary site of ketogenesis and is glycolytic, and gluconeogenesis is highly regulated. Conversely, in the ruminating animal, the ketogenic function of the liver is decreased, and gluconeogensis is more constant and refractory to glycolytic and glucogenic hormonal inputs. This review will focus on key elements of rumen development and differentiation, intestinal growth and metabolism, and liver adaptations in the weaning ruminant.

\section{Rumen Development}

Development of the ruminal epithelium. The rumen is incompletely developed both physically and metabolically at birth (Warner et al., 1956). In the neonate, the rumen does not exhibit the high degree of keratinization characteristic of the mature organ (Gilliland et al., 1962); metabolically, the rumen is essentially nonfunctional with respect to ketogenic capacity (Warner et al., 1956). Following the initiation of solid feed intake by the neonate and the subsequent establishment of the ruminal fermentation, the rumen undergoes both physical and metabolic development. Physical development of the rumen can be further partitioned into 2 aspects: increases in rumen mass and growth of the papillae. Early research indicated that physical stimulation by feed in the rumen could account for measurable increases in both rumen weight and musculature development. The presence of physical bulk does not, however, promote papillary development (Hamada et al., 1976). Thus, for normal development of the ruminal epithelium to progress, a viable ruminal fermentation must be established, suggesting that there is a requirement for the presence of shortchain fatty acid (SCFA) in the ruminal lumen to promote normal papillary development (Sander et al., 1959).

When compared to grain and hay fed control animals, neonatal ruminants maintained solely on milk during the first months of life exhibit limited ruminal development with respect to rumen weight (Tamate et al., 1962), capacity (Smith, 1961; Tamate et al., 1962), papillary growth (Warner et al., 1956; Tamate et al., 1962), degree of keratinization (Gilliland et al., 1962), pigmentation (Tamate et al., 1962) and musculature development (Warner et al., 1956; Smith, 1961;
Tamate et al., 1962; Hamada et al., 1976). The lack of development is likely due to the effective shunting of milk directly to the abomasum by the reflexive closure of the reticular groove (Ørskov et al., 1970), thus preventing substrate for the establishment of a ruminal fermentation from entering the rumen. Accordingly, when milk was infused directly into the rumen, resulting in SCFA production, papillary growth was stimulated (Tamate et al., 1962). Similarly, Lane and Jesse (1997) reported that infusing $50 \%$ of the lamb's estimated net energy requirement in the form of SCFA at physiological concentrations resulted in increases in papillae length. Conversely, use of ruminally inert materials such as nylon bristles (Warner et al., 1956), plastic sponges (Tamate et al., 1962), wood shavings (Smith, 1961), and plastic cubes (Hamada et al., 1976) to simulate the physical stimulus of feed in the rumen resulted in no significant papillary development. Infusions of sodium propionate and sodium butyrate, but not sodium acetate, sodium chloride or glucose, resulted in marked development of the ruminal papillae in calves (Sander et al., 1959; Tamate et al., 1962). A mixture of SCFA salts (propionate and butyrate included) fed as $10 \%$ (wt/wt) of a concentrate starter ration resulted in increased incidence of ruminal parakeratosis, and in all treated animals a thickening of the stratum corneum was reported in calves (Gilliland et al., 1962) and lambs (Rickard and Ternouth, 1965). Increasing amounts of concentrate in the diet resulted in no change in rumen muscularity but did result in increased papillae density and papillae height in calves (Stobo et al., 1966) and lambs (Rickard and Ternouth, 1965). None of these studies were able to definitively distinguish the mechanism responsible for the induction of papillary development. The possibility that butyrate and propionate metabolism by the ruminal epithelium induces an increase in blood flow through the rumen cannot be disregarded as a factor (Sander et al., 1959), nor can the possibility of a direct effect of butyrate or propionate on gene expression within the rumen (Gálfi et al., 1991; Glauber et al., 1991). Wang et al. (1996) reported the selection and identification of cDNA clones encoding 2 small prolinerich proteins, which are characteristically associated with the development of the cornified envelope of stratified squamous epithelial tissues (skin, rumen epithelium) and, thus, may represent excellent molecular markers of physical development. Although these clones exhibited a differential expression pattern throughout development in normally reared lambs, the expression increased gradually, thereby indicating a more ontogenic control rather than a trigger driven change in expression of these gene products. 
Control of proliferation. Ruminal epithelial cell proliferation has been studied both in vivo (Sakata and Tamate, 1976b, 1978) and in vitro (Gálfi et al., 1991) by measuring ${ }^{3} \mathrm{H}$-thymidine incorporation and mitotic indices. Butyric acid infused directly into the rumen of sheep resulted in a stimulation of mitotic indices (number of basal cell nuclei showing mitotic figures/total basal cell nuclei counted; Sakata and Tamate, 1976a, 1976b). However, only 2 animals were observed in this study, and data are confounded by the fact that both animals were fasted throughout the 5 and $7 \mathrm{~d}$, and the effect of butyrate did not appear until 3 or $4 \mathrm{~d}$ subsequent to the initiation of the fast. Thus, from this experiment it is difficult to determine whether butyrate is stimulatory or permissive in promoting mitosis. In a series of similar trials, a single pulse dose of sodium butyrate followed by continuous saline infusion stimulated mitotic indices to a greater extent than a pulse-chase regime with sodium butyrate (Sakata and Tamate, 1976b, 1978). Thus, a rapid but unsustained increase in butyrate in the rumen, which is not observed physiologically, stimulates cell proliferation, as indicated by greater mitotic indices. To a lesser extent than with butyrate, both propionate and acetate have been shown to stimulate mitotic indices when administered as a single dose (Sakata and Tamate, 1979).

Contrary to results in vivo, ${ }^{3} \mathrm{H}$-thymidine incorporation into cellular DNA by isolated ruminal epithelial cells was inhibited over a 24 -h period in a dose-dependent manner by the presence of sodium butyrate ( 2 and $10 \mathrm{mM}$ ) in the medium (Gálfi et al., 1981). Further studies with butyrate in cultures of tissue explants indicate that butyrate tends to arrest cell division of cells in the basal lamina, while increasing the keratinization and protein expression of the other cell types. This results in increased size and cornification of the explant (Gálfi et al., 1991). Moreover, Baldwin (1999) used isolated rumen epithelial cells in 48-h cultures to demonstrate decreased cell proliferation, as determined by MTT assay, in the presence of butyrate or propionate alone, with half-maximal inhibition occurring at concentrations of $0.52 \mathrm{~m} M$ butyrate and $0.93 \mathrm{~m} M$ propionate.

The different responses in vivo and in vitro, and the seemingly contradictory nature of the in vivo reports, is suggestive of an indirect pathway of cell stimulation. Ruminal epithelial mitotic indices have been shown to be stimulated by intravenous insulin infusions (Sakata et al., 1980). Because propionate has been shown to be a stimulator of insulin release in vivo (Sakata et al., 1980), it is possible that insulin could be a mediator in the stimulation of mitosis in the ruminal epithelium. In fact, administration of pen- tagastrin, insulin, and glucagon to isolated ruminal cells all resulted in stimulation of cell proliferation (as detected by ${ }^{3} \mathrm{H}$-thymidine incorporation), while responses to cortisol were inconsistent (Sakata and Tamate, 1978, 1979). Of the additions tested, only insulin was able to overcome the inhibitory effect of butyrate on ${ }^{3} \mathrm{H}$-thymidine incorporation by isolated cells of the stratum basale (Gálfi and Neogrady, 1989). Similar results were observed by Baldwin (1999), where insulin, epidermal growth factor, and IGF-I stimulated cell proliferation to rates 75, 97, and 96\% (MTT assay) of the rates observed in 5\% fetal calf serum-treated controls, respectively. Moreover, the inhibitory action of $1 \mathrm{~m} M$ butyrate was completely overcome by the addition of IGF-I and epidermal growth factor and to a lesser extent by insulin (66\% of the 5\% fetal calf serum-stimulated rate of proliferation). Thus, factors other than direct action by nutrients cannot be eliminated as possible agents controlling ruminal epithelial proliferation, although clear primary candidates have not yet been delineated conclusively.

Neonatal ruminal epithelial metabolism. In the milk-fed ruminant, due to the reflexive closure of the reticular groove and the lack of SCFA in the ruminal lumen, the primary source of energetic substrates are blood borne, derived from intestinally absorbed nutrients. Fatty acids and glucose absorbed in the small intestine must first pass through the liver; thus it has been assumed that glucose is a primary energy substrate of the immature tissue, as is the case with other neonatal tissues (White and Leng, 1980). Early experiments in vitro evaluated rates of oxygen uptake by rumen slices from 14-d-old calf ruminal epithelium (undeveloped) or mature ruminal papillae in the presence of various oxidizable substrates such as glucose, butyrate, and lactate (Giesecke et al., 1979). Oxygen uptake by neonatal rumen was greatest when glucose was present as the oxidizable substrate; however, oxygen consumption by mature rumen papillae increased above basal oxygen uptake when glucose was added, but did not respond as dramatically as neonatal rumen slices (Giesecke et al., 1979). Lactate addition to the media induced a similar pattern of oxygen uptake as that observed with glucose (Giesecke et al., 1979). In contrast, the addition of butyrate stimulated oxygen uptake to a greater degree in mature rumen papillae than in the neonatal rumen. Ketogenesis from butyrate was also substantially lower in the neonatal rumen compared with the mature tissue. In more recent experiments, Baldwin and Jesse (1992) used an isolated rumen epithelial cell system that compared the metabolic capabilities of stratum basale and stratum spinosal cells isolated from lambs at 7 ages during normal development. They observed that glucose was 
Table 1. The relative contribution of visceral organs to whole body oxygen consumption of ruminants at different physiological states.

\begin{tabular}{|c|c|c|c|}
\hline Species/physiological status & $\mathrm{PDV}, \%^{1,2}$ & Hepatic, $\%^{1}$ & Reference \\
\hline Neonatal lambs & 11 & 15 & Edeelstone and Holzman, 1981 \\
\hline Preruminant calves & 17 & 13 & Ortigues et al., 1995 \\
\hline Preruminant calves & 19 & 14 & Martin et al., 1991 \\
\hline Sheep & $19-28$ & $22-41$ & Burrin et al., 1989 \\
\hline Beef steers & & & Eisemann and Nienaber, 1990 \\
\hline Fasted & $18-20$ & $25-26$ & \\
\hline Fed & $20-25$ & $20-21$ & \\
\hline Beef steers & $18-23$ & $17-22$ & Reynolds et al., 1992 \\
\hline Beef steers & $20-24$ & $18-31$ & Huntington et al., 1990 \\
\hline Beef heifers & $23-28$ & $19-26$ & Reynolds et al., 1991 \\
\hline Dairy steers & $25-30$ & 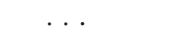 & Huntington et al., 1988 \\
\hline Lactating cows & 20 & 25 & Reynolds et al., 1986 \\
\hline
\end{tabular}

oxidized at moderate rates by cells isolated from 1-, 4- and 7-d-old lambs and at very high rates from 14 - to 49 -d-old lambs. However, by weaning at $56 \mathrm{~d}$, glucose oxidation by the ruminal cells had declined to rates below those observed in ruminal cells from newborn lambs. Butyrate oxidation exhibited a similar pattern; initially rates of oxidation were low followed by high rates of oxidation from $7 \mathrm{~d}$ through weaning. Both butyrate 9 and glucose oxidation rates decreased in the presence of the other oxidizable substrate. Thus, although the ruminal epithelium can use glucose and butyrate as its energetic substrate, neither appears to be the favored substrate. In the same experiments, ketogenic capacity of the isolated cells was apparent by $4 \mathrm{~d}$ of age and did not increase until weaning when an 8-fold increase in BHBA production was observed (Baldwin and Jesse, 1992). Lane et al. (2000) assessed rumen metabolic development of ruminal epithelium in the absence of solid feed intake by maintaining lambs solely on milk replacer and observed the characteristic and marked increase in ketogenic capacity at $42 \mathrm{~d}$ regardless of dietary regimen. While other metabolic parameters did not follow this characteristic development, this is again indicative of an ontogenic response rather than a nutrient triggered event. Moreover, using rumen epithelial RNA isolated from these same experimental animals, Lane et al. (2002) were able to demonstrate an increase in gene transcripts for 3-hydroxy-3-methylglutaryyl-CoA synthase (E. C. 4.1.3.5), despite the lack of significant SCFA production in the rumen. Thus, ontogenic control of some of the critical development changes occurring in the developing ruminant can not be eliminated as a causative factor, despite the large volume of evidence implicating butyrate as the putative trigger for development. Moreover, these processes need not be mutually exclusive events.

\section{Alimentation, Gut Mass, and Metabolic Activity}

Cost of service functions. A large portion of the absorbed nutrients from ruminant gut are modified or used during microbial fermentation in the foregut and also by absorptive tissues of the calf prior to their release into circulation. This results in a decrease in supply of energy and amino acid precursors from a given feed source that are available to productive tissues of the calf. However, this energy and amino acid use cannot be considered a total loss to the calf because the absorptive gut tissues perform a vital service to the productive tissues of the animal. Yet, it does represent a decrease in productive efficiency per unit of feed energy supplied. By functional necessity, the gut and liver are anatomically placed to have access to absorbed nutrients before peripheral tissues. Therefore, gut and liver metabolism determine the availability of most carbon-based nutrients for the support of productive functions and thus are crucial to the health and growth of the calf. In fact, the portal-drained viscera (PDV; includes the digestive tract, pancreas, spleen, and omental and mesenteric fat) represents only 8 to $10 \%$ of body tissues (Seal and Reynolds, 1993), yet accounts for 18 to $25 \%$ of the $\mathrm{O}_{2}$ consumption of the animal, with an additional $25 \%$ being accounted for by the liver (Table 1). While a portion of the energy expended by the gut epithelium is directly associated with the cost of actively absorbing and transporting nutrients for subsequent use by the productive tissues, a majority of the energy expended is used for maintenance of tissue integrity and mass. These maintenance functions of the visceral organs primarily include $\mathrm{Na}+-$ $\mathrm{K}+$-ATPase activity, protein synthesis and degradation, substrate cycling, and urea synthesis (McBride and Kelly, 1990). In fact, the ruminant gastrointestinal tract as a whole is responsible for $40 \%$ of the whole 
body ATP use (McBride and Kelly, 1990). Additionally, a simulation of protein turnover in growing lambs predicts that $19 \%$ of total body ATP expenditure is due to protein turnover and that 25 to $27 \%$ is due to gastrointestinal tract protein turnover (Gill et al., 1989). Based on the aforementioned energetic and nutrient costs, the maintenance of the gastrointestinal tract tissues in the growing ruminant has an extensive impact on whole body metabolism. However, defining the actual cost of the gut tissues is further complicated by the fact that the mass of these tissues changes in response to plane of nutrition, dietary chemical composition, and physiological status of the animal.

Gut growth and metabolic activity. While extensive research has focused on the role of milk and colostral growth factors on ruminant neonatal intestinal development (Blum and Baumrucker, 2002), a paucity of data is available describing the intestinal response during weaning and development of the rumen. Baldwin (2000), using isocaloric diets of either milk replacer or pelleted lamb starter, demonstrated that the physical form of the diet does not impact intestinal mass. However, ruminal mass was exceptionally responsive to the change in form of the diet, likely reflecting the successful shunting of the milk replacer diet past the rumen and disruption of the establishment of a ruminal fermentation. This is consistent with observations made in rats, where weaning has been demonstrated to have no casual role in the growth and differentiation of the intestine (Morisset, 1993). Although intestinal mass changes are not apparent, capacity for nutrient assimilation may be affected. Shirazi-Beechey (1991b) demonstrated that intestinal digestive enzymes are not regulated by solid feed intake. However, Na-glucose cotransporter expression is clearly regulated by the delivery of hexose post-ruminally, indicating the potential for nutrient gene interactions controlling metabolic function of the intestine (Shirazi-Beechey et al., 1991a).

In the growing postweaning ruminant model, a number of data sets are available to assess the impact of dietary energy intake and density on gut growth and oxidative metabolism as it affects the nutrients available for production. Gut mass changes dramatically with changes in metabolizable energy (ME) intake and is highly responsive to changes in level of alimentation (Ferrell et al., 1986; Ferrell, 1988; Burrin et al., 1989, 1991, 1992; Johnson et al., 1990; Freetly et al., 1995). Research by Ferrell and co-workers has convincingly demonstrated a positive relationship between plane of nutrition (level of energy intake) and increased maintenance energy costs associated with the splanchnic tissues (Ferrell et al., 1986; Ferrell, 1988; Burrin et al., 1989, 1991, 1992; Freetly et al.,
1995). The influence of energy intake and density was further defined by Reynolds et al. (1991), who demonstrated in growing heifers a positive relationship between PDV $\mathrm{O}_{2}$ use and both ME intake ( $1 \times$ vs. $2 \times$ maintenance energy intake) and fiber content of the diet ( $75 \%$ forage diet vs. $75 \%$ concentrate diet). The increase in $\mathrm{PDV}_{2}$ use associated with decreased dietary energy density of the diet resulted in a reduction in the partial efficiency of $\mathrm{ME}$ for tissue gain. Our laboratories have conducted a series of experiments (McLeod and Baldwin, 2000; Baldwin and McLeod, 2000) using a similar feeding protocol to that of Reynolds et al. (1991) in growing lambs to determine whether the increase in PDV heat production associated with dietary forage level is due to increased mass or mass specific metabolism. In these experiments, we demonstrated that increasing ME intake and dietary forage resulted in increased ruminal and intestinal growth via cellular hyperplasia (McLeod and Baldwin, 2000). Moreover, the increase in intestinal mass response associated with both ME intake and dietary forage level was largely ( $>90 \%$ ) a result of proliferation within the mucosa. In an effort to delineate mass specific metabolic activity changes associated with ME intake and dietary forage content, isolated rumen epithelial cells and intestinal enterocytes were subjected to in vitro analysis of oxidative metabolism. Oxygen consumption and $\mathrm{Na}+\mathrm{K}+$-ATPase activity were unaffected by dietary regime (McLeod and Baldwin, 2000), which is consistent with earlier work demonstrating that in vitro rates of $\mathrm{O}_{2}$ consumption by sheep rumen, duodenal, and jejunal epithelium were unaffected by level of alimentation (McBride and Milligan, 1985; Rompala et al., 1987; Burrin et al., 1990; Wester et al., 1995). Similarly, $V_{\max }$ (maximal rate of substrate oxidation) and $\mathrm{K}_{\mathrm{ox}}$ (concentration of substrate at which half $\mathrm{V}_{\max }$ oxidation rate is achieved) estimates for the metabolism of specific oxidative substrates by rumen epithelial cells (Baldwin and McLeod, 2000) and intestinal enterocytes (unpublished data) were unaffected by metabolizable energy intake and dietary forage content. This demonstration that cellular oxidative capacity remains constant despite differences in gut cellularity indicates that changes in $\mathrm{PDV} \mathrm{O}_{2}$ consumption are due to changes in mass rather than mass specific activity.

The regulation of gut growth is complex because it is affected by metabolic and trophic hormones as well as chemical and physical dietary factors. Moreover, the cause and effect relationship between metabolizable energy intake and gut growth is largely speculative due to confounding factors such as dietary chemical composition and DMI. In an attempt to define the role of dietary bulk on gut growth, Rompala et al. 
(1988) demonstrated that inert bulk, in the form of polyethylene, stimulated increases in ruminal and colonic tissue mass but failed to elicit a growth response in the small intestine. Similarly, Hamada et al. (1976) found that plastic cubes placed in the rumen of milkfed steers increased musculature development of the rumen, but did not elicit normal epithelial development. Conversely, McLeod et al. (2002) reported that ruminal infusion of starch hydrolyzed at $20 \%$ of metabolizable energy intake increased ruminal mass in growing steers, but abomasal starch infusion failed to elicit an intestinal growth response. This suggests that ruminal growth is responsive to the energy substrate supply, but intestinal tissue growth is not responsive to energy delivery per se. The latter is consistent with the data of Orskov et al. (1979) and Gross et al. (1990), which demonstrated that intestinal atrophy occurs in animals maintained on total intragastric infusion. Furthermore, the results of Gross et al. (1990) tend to suggest $\mathrm{O}_{2}$ consumption by the PDV tissues is lower in animals maintained on total intragastric infusion than those fed alfalfa. In fact, when these data are plotted against $\mathrm{ME}$ intake, total intragastrically infused animals fall well below the expected PDV heat energy expenditure predicted using a regression equation developed from several published PDV heat energy data sets with animals fed a wide range of diets differing in ME intake (Seal and Reynolds, 1993). Taken together, these data show that gut growth is not simply a function of energy substrate supply or dietary chemical composition, but rather a plexus of nutritional and physiological inputs.

A comprehensive discussion of all the growth factors associated with the regulation of gastrointestinal tissues is beyond the scope of this review; however, a brief description of a number of factors that may be of interest is included. Epidermal growth factor and transforming growth factor- $\alpha$ interact with the epidermal growth factor receptor to elicit proliferative responses in epithelial cell types, including intestinal mucosa (Jaeger and Lamar, 1992; Kelly et al., 1992; Tarnawski et al., 1992; Playford et al., 1993) and keratinocytes (Peter et al., 1993; Baldwin, 1999). Epidermal growth factor has also been shown to stimulate ornithine decarboxylase activity (Feldman et al., 1978), which is the rate-limiting step in the conversion of ornithine to polyamines. Polyamines have been linked to increased RNA synthesis (Johnson, 1987) and interestingly, are high in rumen microbial protein fractions. Locally released hormones such as gastrin, cholecystokinin, enteroglucagon, secretin, and bombesin have also been shown to have proliferative effects in intestinal tissue of nonruminants; however, it remains equivocal as to whether they are centrally involved in gut growth and development (Johnson, 1987). In contrast to the aforementioned proliferative factors, somatostatin has been shown to exhibit antiproliferative and antisecretory actions on the gut and pancreatic tissues in nonruminants (Yamada and Chiba, 1989). Although substantially less documented in ruminants, Fachney and Barry (1984) demonstrated that continuous somatostatin infusion $(72 \mathrm{~h})$ in sheep decreased gut tissue mass. Furthermore, McLeod et al. (1997) reported that somatostatin infusion decreased net PDV glucose and alpha-amino nitrogen absorption and reduced splanchnic $\mathrm{O}_{2}$ consumption in sheep. McLeod et al. (1997) further demonstrated that depletion of endogenous somatostatin had opposite effects to those observed for somatostatin infusion, suggesting that somatostatin has a physiological role in the regulation of splanchnic metabolism. Baldwin and McLeod (2002) subsequently asserted that somatostatin exerts its effects via direct action at the cellular level from a series of experiments which demonstrated that increasing somatostatin resulted in a linear decline in glucose oxidation to $\mathrm{CO}_{2}$. However, it is uncertain whether the reduction in glucose oxidation is transporter related or represents a change in cellular oxidation.

\section{Changes in Liver Metabolism in Response to Ruminal Development}

Even though the neonatal and preruminant liver represents a greater percentage of empty BW than that of the adult ruminant (Moulton, 1922), the fraction of whole-body oxygen use attributed to the liver is considerably less (Table 1). This appears to be a function of lower metabolic activity. In vivo measurements (Ortigues et al., 1995; Ortigues and Doreau, 1995) have shown that hepatic metabolic activity of the preruminant calf $\left(2.1 \mu \mathrm{mol} \mathrm{O}{ }_{2} \cdot \mathrm{min}^{-1} \cdot \mathrm{g}^{-1}\right)$ is similar to that of the neonatal lamb $\left(2.8\right.$ to $6.4 \mu \mathrm{mol} \mathrm{O}{ }_{2} \cdot \mathrm{min}^{-}$ ${ }^{1} \cdot \mathrm{g}^{-1}$ ) and lower than that of the adult sheep (4.9 to 9.3 $\left.\mu \mathrm{mol} \mathrm{O}{ }_{2} \cdot \mathrm{min}^{-} \cdot \mathrm{g}^{-1}\right)$. Although ontogenic events cannot necessarily be dismissed, the increase in hepatic metabolic activity most likely reflects changes in the amount and type of substrates metabolized by the liver, e.g., glucose and fatty acids vs. SCFA, as a consequence of rumen development. In developing animals, the peri-weaning digestive adaptation from a preruminant to functional ruminant coincides with a shift from primarily intestinally absorbed glucose, long-chain fatty acids, and milk-derived amino acids to SCFA, ketones, amino acids from feed and microbial sources, and other dietary compounds. Consequently, this change in dietary nutrient pattern and supply causes substantial alterations in hepatic function and energy 
Table 2. Changes in hepatic enzyme activity with the shift in metabolic priorities associated with ruminal development.

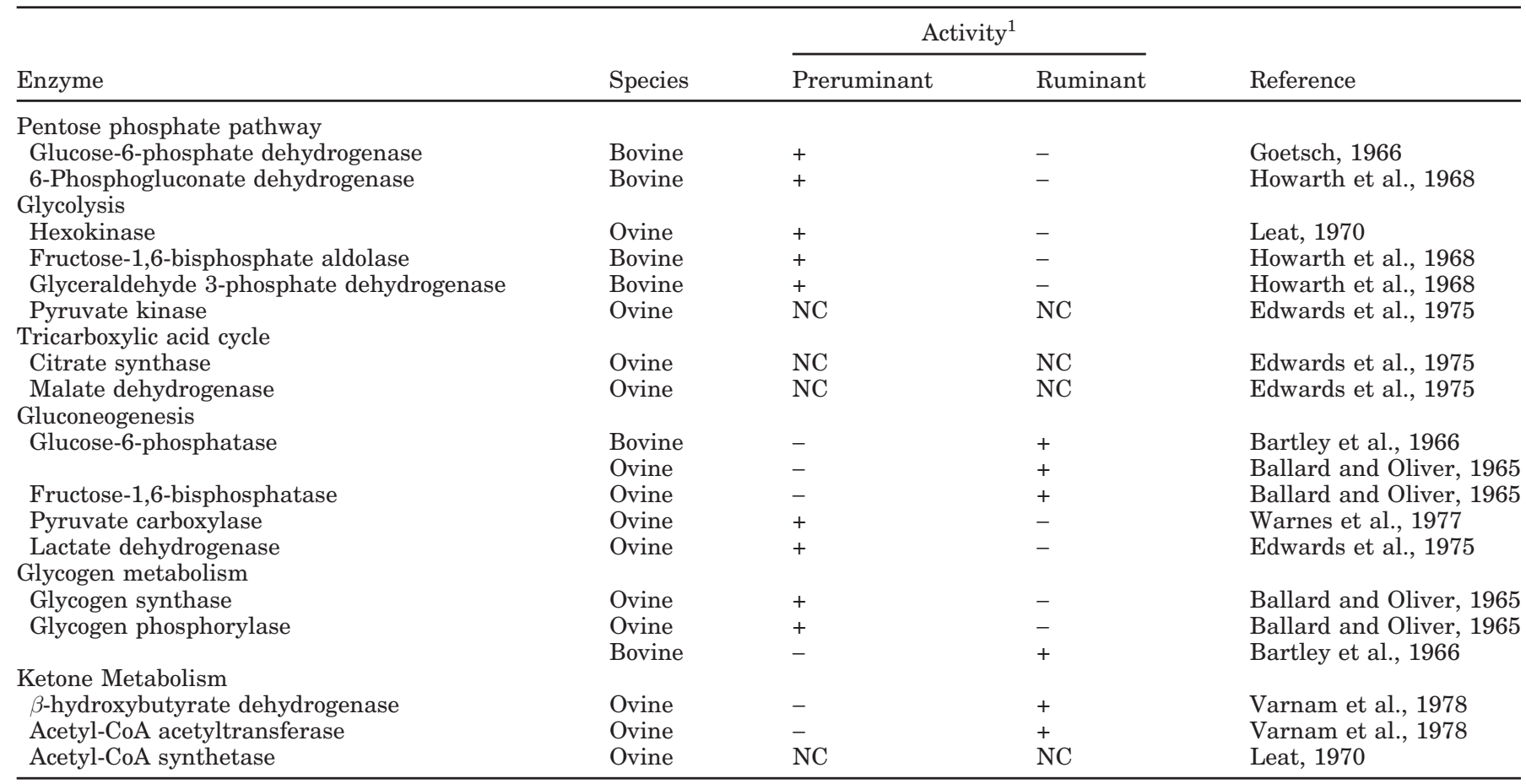

${ }^{1}(+)=$ increased enzyme activity, $(-)=$ reduced enzyme activity, $(\mathrm{NC})=$ no change in enzyme activity.

requiring processes such as glucose and urea synthesis, protein synthesis, maintenance of ion gradients, substrate cycling, and detoxification of compounds (Seal and Reynolds, 1993). Most research directed at elucidating hepatic mechanisms involved with this period of transition have in effect attempted to determine whether the preruminant liver is always equipped to accommodate the digestive adaptations of the foregut or whether the liver undergoes a maturation process of its own in response to ruminal development.

The most notable of changes in principal metabolic processes during ruminal development is the shift from a glycolytic to glucogenic liver (Table 2). As microbial fermentation increases, less carbohydrate is available for postruminal digestion, and the dietary supply of glucose diminishes. These changes in glucose metabolism were reviewed in detail by Leat (1970). There is a basic reduction in enzyme capacity for hepatic glucose oxidation via glycolytic and hexose monophosphate pathways (Bartley et al., 1966) caused by decreased activities of hepatic glucose-6- phosphate dehydrogenase (E.C. 1.1.1.49), 6-phosphogluconate dehydrogenase (E.C. 1.1.1.44), fructose 1,6-bisphosphate aldolase (E.C. 4.1.2.13), and glyceraldehyde 3phosphate dehydrogenase (E.C. 1.2.1.12; Goetsch, 1966; Leat, 1970). Hepatic tissue must now support a larger portion of the animal's glucose requirements. Concurrent with decreased importance of glycolytic pathways is the rapid increase in activity of hepatic gluconeogenic enzymes with ruminal development, glucose 6-phosphatase (E.C. 3.1.3.9) activity having been shown to double during this period (Bartley et al., 1966).

Concomitant with changes in enzyme activity associated with decreased glucose oxidation is the fact that basal rates of hepatic gluconeogenesis from propionate are similar in newborn, weaned, and adult sheep (Ballard and Oliver, 1965) and in cattle (Young et al., 1965; Donkin and Armentano, 1995). Hepatic glucose production is thought to be the primary means of lactate clearance in the preruminant (Edwards et al., 1975). The capacity for hepatic metabolism of L-lactate or pyruvate to glucose is two- to threefold greater in preweaned than adult sheep (Ballard and Oliver, 1965; Savan et al., 1986). More recently, using hepatocyte monolayers taken from preruminating and ruminating calves, Donkin and Armentano (1995) demonstrated that gluconeogenesis from lactate was approximately 10-fold greater in preruminating than ruminating calves. Ortigues et al. (1996) determined the maximum contribution of lactate to hepatic glucose production was $20 \%$ in preruminant calves fitted with chronic indwelling catheters in portal, hepatic, and mesenteric vein and artery. Interestingly, Van der Walt et al. (1983) attributed $20 \%$ of hepatic uptake of lactate being released as glucose in adult sheep. 
This apparent contradiction may be attributable to a species difference, because cattle and sheep show different rates of propionate conversion to lactate by rumen mucosa (reviewed by Bergman, 1990). While preruminants can convert either lactate or propionate to glucose, the inhibition of gluconeogenesis from lactate in ruminants is likely a result of increased availability of propionate (Donkin and Armentano, 1994). Thus, in contrast to preruminant prandial patterns of nutrient delivery, the shift in hepatic gluconeogenic metabolism may be a response to development of the functional rumen generating a more continuous supply of glucogenic substrate in the form of propionate.

Differences in preruminant and ruminant portal nutrient delivery to the liver are also evident in hormonal regulation of liver function. As ruminal development progresses, there is a decreased sensitivity of hepatic gluconeogenesis in response to acute aberrations in insulin and glucagon concentrations. In hepatocytes isolated from preruminants, glucagon effectively increases hepatic gluconeogenesis from propionate and lactate, but had no effect on ruminant hepatocytes (Donkin and Armentano, 1995). Donkin and Armentano (1995) also demonstrated that decreased gluconeogenesis and increased net de novo glycogenesis from propionate in the presence of insulin occurred only in preruminant hepatocytes. Activities of glycogen synthetase (E.C. 2.4.1.11) and phosphorylase (E.C. 2.4.1.1) associated with glycogen formation and degradation were elevated but appeared to decrease to adult levels by 2 to 3 mo (Ballard and Oliver, 1965). Hepatic glycogen reserves of the preruminant typically equal or exceed adult levels (Ballard and Oliver, 1965). However, a short 16-h fast results in consumption of almost all liver glycogen, while similar fasts had little effect on hepatic glycogen in adults (Boda et al., 1962). Much more sensitive to insulin, the young preruminant is similar to nonruminants (Leat, 1970), but concurrent with ruminal development, sensitivity to glucagon is decreased and insulin sensitivity is lost completely (Donkin and Armentano, 1995). Again, because the preruminant experiences prandial patterns of nutrient delivery, extensive hormonal control of hepatic gluconeogenesis is necessary. This is in contrast to the functional ruminant in which the liver receives a more continuous supply of glucogenic substrates and is a steady producer of glucose; therefore, it requires less hormonal control.

One of the most defining characteristics of a fully developed functioning foregut in a fed, nonpregnant, nonlactating animal is ruminal production of ketones. Unlike the nonpregnant, nonlactating adult, in which the foregut is the primary producer of ketones, the preruminant foregut produces negligible amounts of ketones. This is due to the absence of microbial fermentation; consequently, the liver is the primary site of ketogenesis. The immature fetal lamb liver is incapable of acetoacetate synthesis, but hepatic tissue of the term fetus and the 15-wk-old lamb are capable of both synthesis of acetoacetate and conversion to BHBA (Varnam et al., 1970). Following birth, the preruminant liver has the ability to synthesize acetoacetate from acetyl-CoA (Varnam et al., 1978) and from butyrate (Hird and Weidemann, 1964). In developing sheep, hepatic activities of BHBA dehydrogenase (E.C. 1.1.1.30) and acetyl-CoA transferase (E.C. 2.3.1.9) increased with increasing BHBA concentrations but were not as high as activities measured in fed adults when the ruminal epithelium was the primary ketone producer (Varnam et al., 1978). This is a likely indication of the adult hepatic conversion of portal-derived acetoacetate to BHBA by cytosolic BHBA dehydrogenase (Koundakjian and Snoswell, 1970) that results in a net hepatic output of BHBA and uptake of acetoacetate (reviewed by Heitmann et al., 1987). In the event of fasting, the unfed preruminant is capable of hepatic ketogenesis from the time of birth, but does not assume the role of secondary ketone producer until ruminal development is complete.

\section{CONCLUSION}

Rumen development has a clear and major impact on the digestive capabilities and supply of substrates to the growing ruminant. Although a number of studies have been conducted to elucidate the process of rumen development, and differential expression of key regulatory gene products have been identified, the mechanisms controlling ruminal differentiation are not sufficiently understood. Therefore, it is equivocal as to whether ontogenic control and/or nutrient and endocrine factors are the primary mechanism regulating this important process. While intestinal development occurs during the fetal and the perinatal period, nutrient transport capacity changes, as the preruminant animal becomes a ruminant as a result of specific nutrients supplied. In the growing ruminant, dietary effects, i.e., energy intake and dietary energy density, on ruminal and intestinal mass clearly alter protein and energy maintenance requirements. However, it is unclear whether these changes in gut mass affect digestive and absorptive capacities. Fundamental changes in metabolic pathways occur in the liver as a consequence of rumen development, and may be responsible for the increased energetic costs associated with mature ruminant liver function compared with preruminant liver. 


\section{REFERENCES}

Baldwin, R. L., VI. 2000. Sheep gastrointestinal development in response to different dietary treatments. Small Ruminant Res. 35:39-47.

Baldwin, R. L., VI. 1999. The proliferative actions of insulin, insulin-like growth factor-I, epidermal growth factor, butyrate and propionate on ruminal epithelial cells in vitro. Small Ruminant Res. 32:261-268.

Baldwin, R. L., and B. W. Jesse. 1992. Developmental changes in glucose and butyrate metabolism by isolated sheep ruminal cells. J. Nutr. 122:1149-1153.

Baldwin, R. L., VI, and K. R. McLeod. 2000. Effects of diet forage-toconcentrate ratio and metabolizable energy intake on isolated rumen epithelial cell substrate metabolism in vitro. J. Anim. Sci. 78:771-783.

Baldwin, R. L., VI, and K. R. McLeod. 2002. Glucose oxidation by isolated steer duodenal enterocytes in vitro. Pages 217-220 in Energy Metabolism of Farm Animals; Proceedings of the 15th Symposium on Energy Metabolism. A. Chwalibog and K. Jakobsen, eds. Snekkersten, Denmark.

Ballard, F. J., and I. T. Oliver. 1965. Carbohydrate metabolism in liver from foetal and neonatal sheep. Biochem. J. 95:191-200.

Bartley, J. C., R. A. Freedland, and A. L. Black. 1966. Effect of aging and glucose loading on the activities of glucose-6-phosphatase and phosphorylase of livers of cows and calves. Am. J. Vet. Res. 27:1243-1248.

Bergman, E. N. 1990. Energy contributions of volatile fatty acids from the gastrointestinal tract in various species. Physiol. Rev. 70:567-590.

Blum, J. W., and C. R. Baumrucker. 2002. Colostral and milk insulin-like growth factors and related substances: Mammary gland and neonatal (intestinal and systemic) targets. Domest. Anim. Endocrinol. 23:101-110.

Boda, J. M., P. Riley, and T. Wegner. 1962. Tissue glycogen levels in relation to age and some parameters of rumen development in lambs. J. Anim. Sci. 21:252-257.

Burrin, D. G., R. A. Britton, C. L. Ferrell, and M. L. Bauer. 1992. Level of nutrition and visceral organ protein synthetic capacity and nucleic acid content in sheep. J. Anim. Sci. 70:1137-1145.

Burrin, D. G., C. L. Ferrell, J. H. Eisemann, and R. A. Britton. 1991. Level of nutrition and splanchnic metabolite flux in young lambs. J. Anim. Sci. 69:1082-1091.

Burrin, D. G., R. A. Britton, C. L. Ferrell, and M. L. Bauer. 1990. Level of nutrition and visceral organ size and metabolic activity in sheep. Br. J. Nutr. 64:439-448.

Burrin, D. G., C. L. Ferrell, J. H. Eisemann, R. A. Britton, and J. A. Nienaber. 1989. Effect of level of nutrition on splanchnic blood flow and oxygen consumption in sheep. Br. J. Nutr. 62:23-34.

Donkin, S. S., and L. E. Armentano. 1994. Regulation of gluconeogenesis by insulin and glucagon in the neonatal bovine. Am. J. Physiol. 266:R1229-R1237.

Donkin, S. S., and L. E. Armentano. 1995. Insulin and glucagon regulation of gluconeogenesis in preruminating and ruminating bovine. J. Anim. Sci. 73:546-551.

Edelstone, D. I., and I. R. Holzman. 1981. Oxygen consumption by the gastrointestinal tract and liver in conscious newborn lambs. Am. J. Physiol. 240:G297-G304.

Edwards, E. M., U. K. Dhand, M. K. Jeacock, and D. A. L. Shepard. 1975. Activities of enzymes concerned with pyruvate and oxaloacetate metabolism in the heart and liver of developing sheep. Biochim. Biophys. Acta 399:217-227.

Eisemann, J. H., and J. A. Nienaber. 1990. Tissue and whole-body oxygen uptake in fed and fasted steers. Br. J. Nutr. 64:399-411.

Faichney, G. J., and T. N. Barry. 1984. Intravenous somatostatin infusion affects gastrointestinal tract in sheep. Can. J. Anim. Sci. 64(Suppl.):93.

Feldman, E. J., D. Aures, and M. I. Grossman. 1978. Epidermal growth factor stimulates ornithine decarboxylase activity in the digestive tract of the mouse. Proc. Soc. Exp. Biol. Med. 159:400.
Ferrell, C. L. 1988. Contribution of visceral organs to animal energy expenditures. J. Anim. Sci. 66(Suppl.) 3:23-33.

Ferrell, C. L., L. J. Koong and J. A. Nienaber. 1986. Effect of previous nutrition on body composition and maintenance energy costs of growing lambs. Br. J. Nutr. 56:595-605.

Freetly, H. C., C. L. Ferrell, T. G. Jenkins, and A. L. Goetsch. 1995. Visceral oxygen consumption during chronic feed restriction and realimentation in sheep. J. Anim. Sci. 73:843-852.

Gálfi, P., and S. Neogrady. 1989. Epithelial and non-epithelial celland tissue culture from the rumen mucosa. Asian-Austr. J. Anim. Sci. 2:143-149.

Gálfi, P., T. Veresegyházy, S. Neogrády, and F. Kutas. 1981. Effect of sodium n- butyrate on primary ruminal epithelial cell culture. Zender. Vet. Med. 28:259-261.

Gálfi, P., S. Neogrády, and T. Sakata. 1991. Effects of volatile fatty acids on the epithelial cell proliferation of the digestive tract and its hormonal mediation. Pages 49-59 in Physiological Aspects of Digestion and Metabolism in Ruminants: Proceedings of the Seventh International Symposium on Ruminant Physiology. T. Tsuda, Y. Sasaki, and R. Kawashima, eds. Academic Press, Inc., San Diego, CA.

Giesecke, D., U. Beck, S. Wiesmayer, and M. Stangassinger. 1979. The effect of rumen epithelial development on metabolic activities and ketogenesis by the tissue in vitro.. Comp. Biochem. Physiol. 62B:459-463.

Gill, M., J. France, M. Summers, B. W. McBride, and L. P. Milligan. 1989. Simulation of the energy costs associated with protein turnover and $\mathrm{Na}+\mathrm{K}+$-transport in growing lambs. J. Nutr. 119:1287-1299.

Gilliland, R. L., L. J. Bush, and J. D. Friend. 1962. Relation of ration composition to rumen development in early-weaned dairy calves with observations on ruminal parakeratosis. J. Dairy Sci. 45:1211-1217.

Glauber, J. G., N. J. Wandersee, J. A. Little, and G. D. Ginder. 1991. 5'-Flanking sequences mediate butyrate stimulation of embryonic globin gene expressioin in adult erythroid cells. Mol. Cell. Biol. 11:4690-4697.

Goetsch, G. D. 1966. Liver enzyme changes during rumen development in calves. Am. J. Vet. Res. 27:1187-1192.

Gross, K. L., D. L. Harmon, and T. B. Avery. 1990. Portal-drained visceral flux of nutrients in lambs fed alfalfa or maintained by total intragastric infusion. J. Anim. Sci. 68:214-221.

Hamada, T., S. Maeda, and K. Kameoka. 1976. Factors influencing growth of rumen, liver, and other organs in kids weaned from milk replacers to solid foods. J. Dairy Sci. 59:1110-1118.

Heitmann, R. N., D. J. Dawes, and S. C. Sensenig. 1987. Hepatic ketogenesis and peripheral ketone body utilization in the ruminant. J. Nutr. 117:1174-1180.

Hird, F. J. R., and M. J. Weidemann. 1964. Ketone-body synthesis in relation to age of lambs. Biochem. J. 93:423-430.

Howarth, R. E., R. L. Baldwin, and M. Ronning. 1968. Enzyme activities in liver, muscle, and adipose tissue of calves and steer. J. Dairy Sci. 51:1270-1274.

Huntington, G. B., G. A. Varga, B. P. Glenn, and D. R. Waldo. 1988. Net absorption and oxygen consumption by Holstein steers fed alfalfa or orchardgrass silage at two equalized intakes. J. Anim. Sci. 66:1292-1302.

Huntington, G. B., J. H. Eisemann, and J. H. Whitt. 1990. Portal blood flow in beef steers: Comparison of techniques and relation to hepatic blood flow, cardiac output and oxygen uptake. J. Anim. Sci. 68:1666-1673.

Jaeger, L. A., and C. H. Lamar. 1992. Immunolocalization of epidermal growth factor (EGF) and EGF receptors in the porcine upper gastrointestinal tract. Am. J. Vet. Res. 53:1685-1692.

Johnson, D. E., K. A. Johnson, and R. L. Baldwin. 1990. Changes in liver and gastrointestinal tract energy demands in response to physiological workload in ruminants. J. Nutr. 120:649-655.

Johnson, L. R. 1987. Regulation of gastrointestinal growth. Pphysiology of the gastrointestinal tract. 2:301-319.

Kelly, D., M. McFadyen, T. P. King, and P. J. Morgan. 1992. Characterization and autoradiographic localization of the epidermal 
growth factor receptor in the jejunum of neonatal and weaned pigs. Reprod. Fertil. Dev. 4:183-191.

Koundakjian, P. P., and A. M. Snoswell. 1970. Ketone body and fatty acid metabolism in sheep tissues: 3 -Hydroxybutyrate dehydrogenase, a cytoplasmic enzyme in sheep liver and kidney. Biochem. J. 119:49-57.

Lane, M. A., R. L. Baldwin, VI, and B. W. Jesse. 2000. Sheep rumen metabolic development in response to different dietary treatments. J. Anim. Sci. 78:1990-1996.

Lane, M. A., R. L. Baldwin, and B. W. Jesse. 2002. Developmental changes in ketogenic enzyme gene expression during sheep rumen development. J. Anim. Sci. 80:1538-1544.

Lane, M. A., and B. W. Jesse. 1997. Effect of volatile fatty acid infusion on development of the rumen epithelium in neonatal sheep. J. Dairy Sci. 80:740-746

Leat, W. M. F. 1970. Carbohydrate and lipid metabolism in the ruminant during post-natal development. Pages 211-222 in Digestive Physiology and Metabolism in the Ruminant. A. T. Phillipson, ed. Oriel Press, Newcastle Upon Tyne, UK.

Martin, C., I. Ortigues, D. Durand, and M. Vermorel. 1991. Contribution of three tissues to energy metabolism in preruminant calves. Pages 28-31 in Energy Metabolism of Farm Animals: Proceedings of the 12th Symposium. C. Wenk and M. Boessinger, eds. Kartause Ittingen, Switzerland.

McBride, B. W., and J. M. Kelly. 1990. Energy cost of absorption and metabolism in the ruminant gastrointestinal tract and liver: A review. J. Anim. Sci. 68:2997-3010.

McBride, B. W., and L. P. Milligan. 1985. Influence of feed intake and starvation on the magnitude of $\mathrm{Na}+\mathrm{K}+$-ATPase(EC3.6.1.3)dependent respiration in duodenal mucosa of sheep. Br. J. Nutr. 53:605-614.

McLeod, K. R., R. L. Baldwin, VI, D. L. Harmon, C. J. Richards, and W. V. Rumpler. 2002. Influence of Ruminal and Postruminal Starch Infusion on Energy Balance in Growing Steers. Pages 385-388 in Energy Metabolism of Farm Animals; Proceedings of the 15th Symposium on Energy Metabolism. A. Chwalibog and K. Jakobsen, eds. Snekkersten, Denmark.

McLeod, K. R., and R. L. Baldwin, VI. 2000. Effects of diet forageto-concentrate ratio and metabolizable energy intake on visceral organ growth and in vitro oxidative capacity of gut tissues in sheep. J. Anim. Sci. 78:760-770.

McLeod, K. M., M. L. Bauer, D. L. Harmon, C. K. Reynolds, and G. E. Mitchell. 1997. Effects of somatostatin and cysteamine on net nutrient flux across the portal-drained viscera and liver of sheep during intraduodenal infusion of starch hydrolysate and casein. J. Anim. Sci. 75:3026-3037.

Morisset, J. 1993. Regulation and growth and development of the gastrointestinal tract. J. Dairy. Sci. 76:2080-2093.

Moulton, C. R., P. F. Trowbridge, and L. D. Haigh. 1922. Studies in Animal Nutrition. II. Changes in proportions of carcass and offal on different planes of nutrition. Missouri Agric. Exp. Stn. Res. Bull. 54:2-76.

Ørskov, E. R., D. Benzie, and R. N. B. Kay. 1970. The effects of feeding procedure on closure of the oesophageal groove in young sheep. Br. J. Nutr. 24:785-794.

Ørskov, E. R., D. A. Grubb, J. S. Smith, A. J. F. Webster, and W. Corrigal. 1979. Efficiency of utilisation of volatile fatty acids for maintenance and energy retention in sheep. Br. J. Nutr. 41:541-551.

Ortigues, I., C. Martin, and D. Durand. 1996. Circadian changes in net nutrient fluxes across the portal-drained viscera, the liver, and the hindquarters in preruminant calves. J. Anim. Sci. 74:895-907.

Ortigues I., C. Martin, D. Durand, and M. Vermorel. 1995. Circadian changes in energy expenditure in the preruminant calf: Whole animal and tissue level. J. Anim. Sci. 73:552-564.

Peter, R. U., A. Beetz, C. Ried, G. Michel, D. van Beuningen, and T. Ruzicka. 1993. Increased expression of the epidermal growth factor receptor in human epidermal keratinocytes after exposure to ionizing radiation. Rad. Res. 136:65-70.

Playford, R. J., A. C. Woodman, P. Clark, P. Watanapa, D. Vesey, P. H. Deprez, R. C. N. Williamson, and J. Calam. 1993. Effect of luminal growth factor preservation on intestinal growth. Lancet 341:843-848.

Reynolds, C. K., G. B. Huntington, H. F. Tyrrell, and P. J. Reynolds. 1986. Splanchnic tissue and whole animal oxygen consumption by lactating Holstein cows. J. Dairy Sci. 69(Suppl. 1):193. (Abstr.)

Reynolds, C. K., H. F. Tyrrell, and P. J. Reynolds. 1991. Effects of diet forage-to-concentrate ratio and intake on energy metabolism in growing beef heifers: Whole body energy and nitrogen balance and visceral heat production. J. Nutr. 121:994-1003.

Reynolds, C. K., H. Lapierre, H. F. Tyrrell, T. H. Elsasser, R. C. Staples, P. Gaudreau, and P. Brazeau. 1992. Effects of growth hormone-releasing factor and feed intake on energy metabolism in growing beef steers: Net nutrient metabolism by portaldrained viscera and liver. J. Anim. Sci. 70:752-763.

Rickard, M. D., and J. H. Ternouth. 1965. The effect of the increased dietary volatile fatty acids on the morphological and physiological development of lambs with particular reference to the rumen. J. Agric. Sci. 65:371-382.

Rompala, R. E., T. A. Hoagland, and J. A. Meister. 1988. Effect of dietary bulk on organ mass, fasting heat production and metabolism of the small and large intestines in sheep. J. Nutr. 118:1553-1557.

Rompala, R. E., D. E. Johnson, W. V. Rumpler, H. W. Phetteplace, and C. F. Parker. 1987. Level of alimentation and line of breeding on oxygen uptake by ovine jejunal mucosa. Am. J. Physiol. 252:R398-R401.

Sakata, T., and H. Tamate. 1976a. Effect of intraruminal injection of $\mathrm{n}$-sodium butyrate on the mitotic indices in sheep ruminal epithelium. Tohoku J. Agric. Res. 27:133-135.

Sakata, T., and H. Tamate. 1976b. Effect of n-butyrate administration rate on the epithelial cell proliferation in adult sheep rumen: A preliminary report. Tohoku J. Agric. Res. 27:136-138.

Sakata, T., and H. Tamate. 1978. Rumen epithelial cell proliferation accelerated by rapid increase in intraruminal butyrate. J. Dairy Sci. 61:1109-1113.

Sakata, T., and H. Tamate. 1979. Rumen epithelium cell proliferation accelerated by propionate and acetate. J. Dairy Sci. 62:49-52.

Sakata, T., K. Hikosaka, Y. Shiomura, and H. Tamate. 1980. Stimulatory effect of insulin on ruminal epithelium cell mitosis in adult sheep. Br. J. Nutr 44:325-331.

Sander, E. G., H. N. Warner, H. N. Harrison, and J. K. Loosli. 1959. The stimulatory effect of sodium butyrate and sodium propionate on the development of rumen mucosa in the young calf. J. Dairy Sci. 42:1600-1605.

Savan, P. M. J., M. K. Jeacock, and D. A. L. Shepard. 1986. Gluconeogenesis in foetal, suckling, and weaned lambs: The effect of glucagon. J. Agric. Sci. 106:259-264.

Seal, C. J., and C. K. Reynolds. 1993. Nutritional implications of gastrointestinal and liver metabolism in ruminants. Nutr. Res. Rev. 6:185-202.

Shirazi-Beechey, S. P., B. A. Hirayama, Y. Wang, D. Scott, M. W. Smith, and E. M. Wright. 1991a. Ontogenic development of lamb intestinal sodium-glucose co-transporter is regulated by diet. J. Physiol. 437:699-708.

Shirazi-Beechey, S. P., M. W. Smith, Y. Wang, and P. S. James. 1991b. Postnatal development of lamb intestinal digestive enzymes is not regulated by diet. J. Physiol. 437:691-698.

Smith, R. H. 1961. The development and function of the rumen in milk-fed calves. II. Effect of wood shavings in the diet. J. Agric. Sci. 56:105-113.

Stobo, I. J. F., J. H. B. Roy, and H. J. Gaston. 1966. Rumen development in the calf. Br. J. Nutr. 20:171-188.

Tamate, H., A. D. McGilliard, N. L. Jacobson, and R. Getty. 1962. Effect of various dietaries on the anatomical development of the stomach in the calf. J. Dairy Sci. 45:408-420.

Tarnawski, A., S.-Y. Lu, J. Stachura, and I. J. Sarfeh. 1992. Adaptation of gastric mucosa to chronic alcohol administration is associated with increased mucosal expression of growth factors and their receptor. Scan. J. Gastroenterol. 27:59-63. 
Van der Walt, J. G., G. D. Baird, and E. N. Bergman. 1983. Tissue glucose and lactate metabolism and interconversions in pregnant and lactating sheep. Br. J. Nutr. 50:267-280.

Varnam, G. C. E., M. K. Jeacock, and D. A. L. Shepherd. 1970. Formation and interconversion of ketone bodies in tissues of developing lambs. Biochem. J. 120:30P.

Varnam, G. C. E., M. K. Jeacock, and D. A. L. Shepherd. 1978. Hepatic ketone-body metabolism in developing sheep and pregnant ewes. Br. J. Nutr. 40:359-367.

Wang, L-Q, R. L. Baldwin VI, and B. W. Jesse. 1996. Identification of two cDNA clones encoding small proline-rich proteins expressed in sheep ruminal epithelium. Biochem. J. 317:225-233.

Warner, R. G., W. P. Flatt, and J. K. Loosli. 1956. Dietary factors influencing the development of the ruminant stomach. Agric. Food Chem. 4:788-801.
Warnes, D. M., R. R. Seamark, and F. J. Ballard. 1977. The appearance of gluconeogenesis at birth in sheep. Biochem. J. 162:627-634.

Wester, T. J., R. A. Britton, T. J. Klopfenstein, G. A. Ham, D. T. Hickok, and C. R. Krehbiel. Differential effects of plane of protein or energy nutrition on visceral organs and hormones in lambs. J. Anim. Sci. 73:1674-1688.

White, R. G., and R. A. Leng. 1980. Glucose metabolism in feeding and postabsorptive lambs and mature sheep. Comp. Biochem. Physiol. 67A:223.

Yamada, T., and T. Chiba. 1989. Somatostatin. Page 431 in Handbook of Physiology: The Gastrointestinal System II. S. T. Schultz and G. M. Makhlouf, eds. Oxford Univ. Press, Oxford, UK.

Young, J. W., S. B. Tove, and H. A. Ramsey. 1965. Metabolism of acetate, propionate, and n-butyrate in young milk-fed calves. J. Dairy Sci. 48:1079-1087. 